\title{
TINJAUAN YURIDIS PENDAFTARAN HAK TANGGUNGAN DALAM PELAYANAN HAK TANGGUNGAN TERINTEGRASI SECARA ELEKTRONIK
}

Oleh :

Jefri Guntoro, Emelia Kontesa, Herawan Sauni

\begin{abstract}
Abstrak
Penelitian ini dilakukan untuk memperoleh gambaran tentang pendaftaran Hak Tanggungan secara elektronik yang telah diterbitkan Peraturan Menteri Agraria dan Tata Ruang/Kepala Badan Pertanahan Nasional Nomor 9 Tahun 2019 tidak semua proses pendaftaran Hak Tanggungan dilakukan secara elektronik. Metode Penelitian yang digunakan adalah metode penelitian hukum normatif. Sedangkan metode pengumpulan data yang digunakan adalah metode pendekatan undang-undang, konseptual dan historis. Hasil penelitian menunjukan bahwa, pendaftaran Hak Tanggungan secara elektronik dilakukan melalui Sistem Hak Tanggungan Elektronik oleh PPAT dan Kreditur dengan mengupload dokumen persyaratan secara elektronik sampai mendapat sertipikat Hak Tanggungan dan catatan Hak Tanggungan pada buku tanah dan Sertipikat Hak Atas Tanah atau Hak Hak Milik Atas Satuan Rumah Susun dalam bentuk elektronik, dan juga pendaftaran Hak Tanggungan secara elektronik masih memiliki kelemahan antara lain Sertipikat Hak Atas Tanah Atau Hak Milik Atas Satuan Rumah Susun harus atasnama debitur dan belum diaturnya mekanisme sindikasi kredit.
\end{abstract}

Kata Kunci : Pendaftaran, Sistem Elektronik, Hak Tanggungan 


\section{A. Pendahuluan}

Kementerian Agraria dan Tata Ruang/Badan Pertanahan Nasional mempunyai peranan penting dalam peruntukan tanah, pengurusan hak milik tanah pemerintah dan individual, penertiban surat-surat yang bersangkutan dengan kepemilikan tanah yang merupakan kunci penghubung antara rakyat dengan pemerintah serta pelayanan pemerintah kepada rakyatnya.

Seiring perkembangan ekonomi dalam masyarakat tentu menyebabkan naiknya kebutuhan bagi masyarakat akan menjadi meningkat pesat sehingga masyarakat membutuhkan dana berupa uang. Masyarakat tidak seluruhnya memiliki dana berlebih, karena pada dasarnya terdapat beberapa kelompok masyarakat yang belum memiliki ekonomi yang baik. Atas dasar kebutuhan yang tinggi dan ekonomi yang belum bisa memenuhi kebutuhan tersebutlah maka masyarakat banyak melakukan peminjaman atas uang kepada pihak bank. Bank merupakan lembaga yang perantara bagi pihak-pihak yang mempunyai kelebihan dana dengan pihak-pihak yang kekurangan atau memerlukan dana yang memiliki fungsi menerima dan menyalurkan dana pada masyarakat.
Peminjaman uang oleh masyarakat sebagai pemilik utang (debitur) dan pihak bank selaku pemberi pinjaman atau pemilik piutang (kreditur) dilakukan melalui perjanjian kredit. Perjanjian kredit sebagai perjanjian pokok, dimana terjadi pemufakatan antara debitur dan kreditur berupa hubungan hukum. Perjanjian kredit ini memiliki jangka waktu tertentu, dalam batas waktu terakhir tentu saja debitur selaku peminjam uang harus mengembalikan pinjaman uang tersebut kepada kreditur berikut dengan bunganya. Dalam proses pengembalian tersebut tentu terdapat kekhawatiran dari pihak kreditur akan kemungkinan tidak mampunya debitur mengembalikan dana yang dipinjam sesuai dengan perjanjian kredit yang ada. Untuk mengurangi kekhawatiran dan mendapatkan kepercayaan, sebelum terjadi perjanjian kredit tersebut tentu pihak kreditur harus melakukan prinsip kehati-hatian. Prinsip kehati-hatian penting bagi bank sebelum diberikan pinjaman uang pada debitur, karena prinsip ini untuk mengetahui:

a. Watak dari debitur apakah memiliki watak baik dalam berbisnis dan memiliki tanggung jawab dalam 
pengembalian pinjaman atau tidak;

b. Kemampuan membayar debitur secara finansial untuk mengembalikan pinjaman;

c. Modal debitur untuk mengetahui kemampuan debitur memikul beban pembiayaan;

d. Jaminan harus bernilai lebih dari pinjaman debitur, yang mana jika ada masalah jaminan ini dapat digunakan untuk melunasi utang debitur;

e. Kondisi ekonomi untuk tahu apakah usaha debitur memiliki prospek kedepan yang bagus atau tidak.

Dari prinsip kehati-hatian yang dipaparkan ini dapat diketahui, jaminan merupakan unsur penting dalam perjanjian kredit guna memberikan kepercayaan kepada kreditur dimana setelah dipenuhi 4 unsur lainnya maka perlu adanya jaminan dari debitur bahwa ia dapat mengembalikan pinjaman tersebut. Jaminan ini sendiri berfungsi agar kreditur dapat segera mendapatkan pelunasan utangnya apabila debitur wanprestasi dengan melalui pelelangan atas jaminan tersebut. Pemberian jaminan ini harus dengan perjanjian pembebanan jaminan, selaku perjanjian tambahan karena adanya perjanjian pokok. Penjanjian pembebanan jaminan ini berupa jaminan hak tanggungan. Pengertian hak tanggungan pada Pasal 1 angka 1 Undang-Undang Republik Indonesia Nomor 4 Tahun 1996 Tentang Hak Tanggungan Atas Tanah Beserta BendaBenda Yang Berkaitan Dengan Tanah (UUHT) menentukan "hak tanggungan adalah hak jaminan yang dibebankan pada hak atas tanah sebagaimana dimaksud dalam UndangUndang Nomor 5 tahun 1960 tentang Peraturan Dasar Pokok-Pokok Agraria (UUPA), berikut atau tidak berikut benda-benda lain yang merupakan satu kesatuan dengan tanah itu, untuk pelunasan utang tertentu, yang memberikan kedudukan yang diutamakan kepada kreditur tertentu terhadap krediturkreditur lain". Perjanjian pembebanan hak tanggungan dituangkan dalam bentuk Akta Pemberian Hak Tanggungan (APHT) oleh Pejabat Pembuat Akta Tanah (PPAT) selaku pejabat berwenang dalam membentuk APHT yang ditentukan Pasal 1 angka 4 UUHT.

Dalam APHT agar memiliki kekuatan hukum perlu dilakukan suatu pendaftaran pada Kantor Pertanahan. Pendaftaran hak tanggungan, awalnya dilaksanakan manual, 
dimana pihak pemohon yaitu, PPAT mengirim APHT dan warkah lainnya kepada Kantor Pertanahan paling lambat 7 hari setelah penandatanganan akta, sebagaimana diatur pada Pasal 13 ayat (2) UUHT. Seiring perkembangan teknologi pendaftaran hak tanggungan pun berubah dimana pendaftaran tersebut dilakukan melalui elektronik setelah berlakunya Peraturan Menteri Agraria dan Tata Ruang/Kepala Badan Pertanahan Nasional Nomor 9 Tahun 2019 Tentang Pelayanan Hak Tanggungan Terintegrasi secara elektronik. Akan tetapi berdasarkan pengamatan sementara tidak semua proses pendaftaran hak tanggungan dilakukan secara elektronik, berdasarkan hal tersebut maka perlu dilakukan penelitian hukum terhadap Peraturan Menteri Agararia dan Tata Ruang/Kepala Badan Pertanahan Nasional Nomor 9 Tahun 2019 tersebut. Berdasarkan uraian sebagaimana diatas, permasalahan yang akan dikaji dalam artikel ini adalah bagaimana mekanisme pelayanan pendaftaran hak tanggungan terintegrasi secara elektronik dan bagaimana kendalakendala pelayanan pendaftaran Hak Tanggungan terintegrasi secara elektronik.

\section{B. Metode Penelitian}

Artikel ini merupakan jenis penelitian yuridis normatif yang mengkaji pelayanan
Hak Tanggungan dalam pelaksanaan pendaftaran Hak Tanggungan secara elektronik yang diatur dalam Peraturan Menteri Agraria Nomor 9 Tahun 2019. Pendekatan yang digunakan untuk menjawab permasalahan dalam artikel ini adalah:

(1) Pendekatan Undang-Undang (statutes approach), (2) Pendekatan konseptual (conceptual approach) serta (3) Pendekatan historis (historical approach). Artikel ini menggunakan bahan hukum primer yaitu bahan hukum yang bersifat mengikat yang mencakup peraturan perundang-undangan yang terkait dengan permasalahan, dan bahan hukum sekunder, yang berupa bahanbahan hukum yang menjelaskan lebih lanjut dan memberi keterangan mengenai bahan hukum primer. Literatur, berupa buku dan jurnal hukum dipergunakan sebagai bahan hukum sekunder. Artikel-artikel dari internet juga dipakai dalam penelitian ini sebagai bahan hukum tersier.

Teknik studi kepustakaan digunakan untuk mengumpulkan bahan hukum primer dan sekunder untuk mencatat kutipankutipan dari pelaksanaan studi kepustakaan. Metode analisis yang digunakan dalam penelitian ini yaitu metode analisis yang menggunakan logika deduktif, artinya metode menarik kesimpulan yang bersifat 
khusus dari pernyataanpernyataan yang bersifat umum.

\section{Hasil dan Pembahasan}

1. Mekanisme Pelayanan Pendaftaran

Hak Tanggungan Terintegrasi Secara

\section{Elektronik}

Berdasarkan Pasal 7 ayat (1) Peraturan Menteri Agraria dan Tata Ruang/Kepala Badan Pertanahan Nasional Nomor 9 Tahun 2019, yang dapat menggunakan layanan Sistem Hak Tanggungan Elektronik disebut pengguna Hak Tanggungan adalah perseorangan/badan hukum selaku kreditor dan Aparatur Sipil Negara Kementerian yang bertugas melayani Hak Tanggungan yaitu Kementerian Agraria dan Tata Ruang/Badan Pertanahan Nasional (Kementerian ATR/BPN). Pada awal sebelum proses penjaminan Hak Tanggungan Elektronik dilakukan, pengguna harus terdaftar terlebih dahulu dengan ketentuan sebagai berikut:

1. Pengguna layanan Sistem Hak Tanggungan Secara Elektronik, terdiri dari perseorangan/badan hukum selaku kreditur dan Aparatur Sipil Negara Kementerian yang bertugas melayani Hak Tanggungan;
2. Terhadap perseorangan/badan hukum sebagaimana dimaksud sebelumnya harus menjadi Pengguna Terdaftar pada Sistem Hak Tanggungan Secara Elektronik, dengan memenuhi persyaratan:

a. Mempunyai domisili elektronik;

b. Surat Keterangan Terdaftar di OJK;

c. Pernyataan pemenuhan persyaratan dan kriteria serta ketentuan sebagai Pengguna Terdaftar; dan

d. Syarat lainnya yang ditentukan oleh Kementerian. Kementerian Agraria dan Tata Ruang/Badan Pertanahan Nasional yang dalam

hal ini yakni Kantor Pertanahan melakukan verifikasi atas pendaftaran dan berhak menolak pendaftaran dimaksud.

Secara garis besar, mekanisme penjaminan Hak Tanggungan dengan Sistem Hak Tanggungan Elektronik sebagai berikut: 
1) Pengguna terdaftar mengajukan permohonan layanan Hak Tanggungan secara elektronik melalui Sistem Hak Tanggungan Elektronik yang telah disediakan oleh Kementerian Agraria dan Tata Ruang/Badan Pertanahan Nasional serta melengkapi persyaratan permohonan sesuai dengan ketentuan peraturan perundangundangan;

2) Pemohon harus membuat surat pernyataan mengenai pertanggungjawaban keabsahan dan kebenaran data Dokumen Elektronik yang diajukan. Persyaratan permohonan berikut dengan surat pernyataan tersebut dibuat dalam bentuk Dokumen Elektronik.

3) Khusus mengenai persyaratan berupa Sertipikat Hak Atas Tanah atau Hak Milik Atas Satuan Rumah Susun harus atas nama Debitur;

4) Permohonan layanan yang telah diterima oleh Sistem Hak Tanggungan Elektronik akan diberikan tanda bukti pendaftaran permohonan yang diterbitkan oleh sistem. Bukti pendaftaran permohonan dimaksud paling sedikit memuat antara lain nomor berkas pendaftaran permohonan; tanggal pendaftaran permohonan; nama pemohon; dan kode pembayaran biaya layanan;

5) Permohonan diproses setelah data permohonan dan biaya pendaftaran permohonan terkonfirmasi oleh sistem elektronik. Berdasarkan Pasal 12 Peraturan Menteri Agraria dan Tata Ruang/Kepala Badan Pertanahan Nasional Nomor 9 Tahun 2019, layanan Hak Tanggungan dikenakan biaya sesuai dengan ketentuan peraturan perundang-undangan mengenai Penerimaan Negara Bukan Pajak yang berlaku pada Kementerian Agraria dan Tata Ruang/Badan Pertanahan Nasional.

6) Setelah mendapatkan bukti pendaftaran permohonan, pemohon melakukan pembayaran biaya melalui bank persepsi paling lambat 3 (tiga) hari setelah tanggal pendaftaran permohonan.

7) Permohonan diproses setelah data permohonan dan biaya pendaftaran permohonan terkonfirmasi oleh sistem elektronik. Dalam hal pembayaran biaya pendaftaran oleh 
pemohon tidak terkonfirmasi oleh sistem, pemohon dapat melakukan konfirmasi secara langsung ke Kantor Pertanahan atau Layanan Pengaduan. Dalam hal jangka waktu berakhir dan Pemohon tidak melakukan pembayaran maka permohonan dinyatakan batal.

8) Penerbitan hasil layanan Hak Tanggungan dilakukan pada hari ke-7 (tujuh) setelah pengajuan permohonan terkonfirmasi.

9) Sistem Hak Tanggungan Elektronik akan menerbitkan hasil layanan hak tanggungan berupa Sertipikat Hak Tanggungan; dan catatan hak tanggungan pada buku tanah dan Sertipikat Hak Atas Tanah atau Hak Milik Atas Satuan Rumah Susun.

10) Pencatatan Hak Tanggungan pada Sertipikat Hak Atas Tanah atau Hak Milik Satuan Rumah Susun dapat dilakukan oleh kreditor dengan cara mencetak catatan yang diterbitkan oleh Sistem Hak Tanggungan Elektronik dan melekatkan hasil cetakan catatan tersebut pada Sertipikat Hak Atas Tanah atau Hak Milik Satuan Rumah Susun.
Dokumen Elektronik, Sertipikat Hak Tanggungan yang diterbitkan oleh Sistem Hak Tanggungan Elektronik diberikan tanda tangan elektronik. Tanda Tangan Elektronik adalah tanda tangan yang terdiri atas Informasi Elektronik yang dilekatkan, terasosiasi atau terkait dengan Informasi Elektronik lainnya yang digunakan sebagai alat verifikasi dan autentikasi. Tanda Tangan Elektronik dilakukan sesuai dengan ketentuan peraturan perundang-undangan yaitu Peraturan Menteri Agraria dan Tata Ruang/Kepala Badan Pertanahan Nasoinal Nomor 3 Tahun 2019 tentang Penerapan Tanda Tangan elektronik. Tanda tangan elektronik tersebut dapat digunakan untuk memberikan persetujuan dan/atau pengesahan suatu dokumen elektronik pertanahan dalam penyelenggaraan tugas dan fungsi Kementerian. Adapun hal yang perlu digarisbawahi yaitu tandatangan elektronik hanya dapat dilakukan setelah penandatangan memiliki sertipikat elektronik.

\section{Kendala-kendala Pelayanan} Pendaftaran Hak Tanggungan Terintegrasi

Secara Elektronik

1) Pengguna sistem Hak Tanggungan Secara Elektronik tersebut harus menjadi Pengguna Terdaftar syarat untuk menjadi 
pengguna Hak Tanggungan Secara Elektronik tersebut diatur dalam Pasal 7 ayat (3) yaitu meliputi:

a. Domisili elektronik;

b. Surat keterangan terdaftar di OJK;

c. Pernyataan pemenuhan persyaratan dan kriteria serta persetujuan ketentuan sebagai pengguna terdaftar; dan

d. Syarat lainnya yang ditentukan oleh Kementerian.

Dalam ketentuan umum Pasal 1 angka 2 Peraturan Menteri Agraria dan Tata Ruang/Kepala Badan Pertanahan Nasional Nomor 9 Tahun 2019 disebutkan bahwa kreditur adalah pihak yang berpiutang dalam hubungan utang-piutang tertentu. Kreditur bisa berbentuk perorangan ataupun badan hukum. Kreditur yang berbentuk perorangan dalam melakukan perjanjian maka haruslah seorang yang cakap hukum sebagaimana dimaksud dalam Pasal $1329^{1}$ juncto $1330^{2}$ KUHPerdata. Sedangkan

\footnotetext{
1 Pasal 1329 Setiap orang adalah cakap untuk membuat perikatan-perikatan, jika ia oleh undangundang tidak dinyatakan tak cakap.

2 Pasal 1330 Tak cakap untuk membuat suatu perjanjian adalah: 1. Orang-orang yang belum dewasa;

Mereka yang ditaruh di bawah pengampuan; 3.orangorang perempuan, dalam hal-hal yang ditetapkan oleh undang-undang, dan pada umumnya semua orang kepada siapa undang-undang telah melarang
}

apabila subjek hukumnya berupa badan hukum, maka tidak hanya dilihat pada person/orangnya saja karena selain cakap hukum tetapi harus dilihat pula pada kewenangannya sebagaimana diatur dalam anggaran dasar yang menjadi aturan main atau konstitusi dari badan hukum tersebut seperti misalnya pada badan hukum PT, dimana berdasarkan ketentuan anggaran dasar Direktur/2 (dua) orang Direktur berwenang mewakili Direksi PT, selain itu Direktur yang bersangkutan harus pula cakap hukum, dan juga dalam melakukan perbuatan hukum tertentu tetap harus memperhatikan ketentuan anggaran dasar yang lain seperti misalnya diperlukannya persetujuan dari organ lain dari PT tersebut yaitu Dewan Komisaris ataupun RUPS tergantung dari perbuatan hukum yang akan dilakukan oleh Direksi seperti misalnya mengambil uang di bank ataukah menjaminkan asset.

Salah satu syarat sebagai pengguna Hak Tanggungan Secara Elektronik ini dalam Peraturan Menteri Agraria dan Tata Ruang/Kepala Badan Pertanahan Nasional Nomor 9 Tahun 2019 yaitu Surat Keterangan Terdaftar di OJK. Berdasarkan hasil penelitian syarat ini

membuat prejanjian-perjanjian tertentu. 
merupakan syarat memberatkan dan menghalangi, dikarenakan:

a. Dalam Pasal 9 UUHT disebutkan bahwa Pemegang Hak Tanggungan adalah orang perseorangan atau badan hukum yang berkedudukan sebagai pihak yang berpiutang, dengan demikian yang dapat menjadi pemegang Hak Tanggungan adalah siapapun juga yang berwenang melakukan perbuatan perdata untuk memberikan utang, yaitu baik itu perseorangan warga Negara Indonesia ataupun asing, baik itu badan hukum Indonesia ataupun badan hukum asing.

b. Otoritas Jasa Keuangan (OJK) merupakan lembaga independen dan bebas dari campur tangan pihak lain, yang mempunyai fungsi, tugas, dan wewenang pengaturan, pengawasan, pemeriksaan dan penyidikan, dan mempunyai ruang lingkup tugas pengaturan dan pengawasan kepada Sektor Perbankan, Sektor Pasar Modal, Sektor Perasuransian, Sektor Dana Pensiun, Sektor Lembaga Pembiayaan. Dalam pengaturan dan pengawasan tersebut, OJK mengeluarkan regulasi-regulasi diantaranya yaitu berupa Peraturan Otoritas Jasa Keuangan atau yang sering disebut POJK. POJK ini ditujukan kepada Pelaku Usaha Jasa Keuangan (PUJK) yang berbentuk badan hukum dan terdaftar serta diawasi oleh OJK seperti Bank Umum, Bank Perkreditan Rakyat, Perusahaan Efek, Penasihat Investasi, Bank Kustodian, Dana Pensiun, Perusahaan Asuransi, Perusahaan Reasuransi, Lembaga Pembiayaan, Perusahaan Gadai, dan Perusahaan Penjaminan, baik yang melaksanakan kegiatan usahanya secara konvensional maupun secara syariah. POJK ini tidak ditujukan kepada perseorangan ataupun badan hukum yang bukan merupakan PUJK terdaftar di OJK, Sehingga syarat Surat Keterangan Terdaftar pada Otoritas Jasa Keuangan merupakan syarat yang menjadi kendala, karena jika memang syarat tersebut dipenuhi, maka bagi masyarakat baik perseorangan ataupun badan 
hukum yang tidak bergerak di industri keuangan dan tidak terdaftar di OJK tidak dapat mendapatkan Surat Keterangan Terdaftar di OJK, sehingga tidak dapat memanfaatkan pelayanan Hak Tanggungan Secara Elektronik tersebut. Mungkin salah satu tujuan yang ingin dicapai pembentuk Peraturan Menteri Agraria dan Tata Ruang/Kepala Badan Pertanahan Nasional Nomor 9 Tahun 2019 tersebut, yaitu agar masyarakat dalam meminjam uang hanya kepada PUJK yang terdaftar dan diawasi oleh OJK dan tidak menggunakan rentenirrentenir baik itu perorangan maupun yang berbentuk badan hukum.

2) Dalam Pasal 9 ayat (5) Peraturan Menteri Agraria dan Tata Ruang/Kepala Badan Pertanahan Nasional Nomor 9 Tahun 2019 disebutkan bahwa persyaratan berupa sertipikat hak atas tanah atau hak milik atas satuan rumah susun harus nama debitur.

Pasal 9 ayat (5) tersebut bertentangan dengan UUHT, karena dengan ketentuan tersebut akan menghambat praktek perkreditan, dimana dalam dunia perkreditan, jaminan yang diberikan debitur belum tentu atasnama debitur sendiri, bisa atasnama suami atau istri, atau orang tua, adik atau kakek, atau siapapun juga termasuk juga atasnama badan hukum. Pemberian jaminan atasnama orang lain itu tidak dilarang oleh undang-undang, dalam ruang lingkup hukum perdata tidak mempermasalahkan siapa yang memberikan jaminan apakah debitur itu sendiri ataukah pihak ketiga, tetapi yang dipermasalahkan apakah pemberi jaminan tersebut cakap dan berwenang. Terlibatnya Pihak ketiga ini dapat diartikan bahwa pihak ketiga menanggung pelunasan atas kredit yang diberikan kepada debitur, sebagaimana diatur dalam Pasal 1820 KUHPerdata, dimana disebutkan bahwa:

"Penanggungan adalah suatu perjanjian dengan mana seorang pihak ketiga, guna kepentingan siberpiutang, mengikatkan diri untuk memenuhi perikatan si berhutang, manakala orang ini sendiri tidak memenuhinya". 
Dalam UUHT Pasal 8 disebutkan bahwa Pemberi Hak Tanggungan adalah orang perserorangan atau badan hukum yang mempunyai kewenangan untuk melakukan perbuatan hukum terhadap obyek Hak Tanggungan yang bersangkutan. Ketentuan Pasal 8 tersebut tidak mempermasalahkan kalau yang berhak memberi jaminan harus debitur, disini yang ditekankan yaitu orang atau badan hukum yang memberikan jaminan haruslah pihak yang berwenang dalam melakukan perbuatan hukum dalam hal ini pemberian jaminan Hak Tanggungan, dan juga mengingat ketentuan dalam Pasal 4 UUHT dimana disebutkan mengenai macam-macam obyek Hak Tanggungan, dimana dalam penjelasan Pasal 4 UUHT tersebut juga tidak disebutkan mengenai obyek Hak Tanggungan tersebut harus milik atau terdaftar atasnama siapa, jadi dapatlah dikatakan bahwa obyek Hak Tanggungan bisa merupakan milik pihak ketiga baik milik perorangan ataupun milik Badan Hukum. Subyek dan obyek Hak Tanggungan dalam UUHT memberikan batasan yang luas mengenai kepemilikan tanah yang dapat dijaminkan serta dimungkinkannya subyek Hak Tanggungan atau Pemberi Hak Tanggungan adalah pihak ketiga dan obyek Hak Tanggungan adalah tanah yang dibawah kepemilikan pihak ketiga, yang terpenting Pemberi Hak Tanggungan cakap dan mempunyai kewenangan pada saat perjanjian Hak Tanggungan dilakukan.

3) Dalam Peraturan Menteri Agraria dan Tata Ruang/Kepala Badan PertanahanNasional Nomor 9 Tahun 2019 tidak diatur mengenai mekanisme pendaftaran Hak Tanggungan dimana kreditur terdiri dari beberapa kreditur yang merupakan sindikasi kredit. Dalam Peraturan Menteri Agraria dan Tata Ruang/Kepala Badan Pertanahan Nasional Nomor 9 Tahun 2019 tidak diatur mengenai kreditur dalam hal sindikasi kredit, dimana dalam sindikasi kredit sertipikat hak atas tanah pada umumnya tercantum nama dari krediturkreditur tersebut pada sertipikat Hak Tanggungan dan pada sertipikat hak atas tanah tersebut. 
4) Permohonan pendaftaran Hak Tanggungan Secara Elektronik menjadi kewajiban kreditur. Dalam Peraturan Menteri Agraria dan Tata Ruang/Kepala Badan Pertanahan Nasional Nomor 9 Tahun 2019 tersebut, kewajiban untuk memohon pendaftaran Hak Tanggungan elektronik menjadi tanggung jawab dari kreditur, sedangkan pada Pasal 13 ayat (2) UUHT ditentukan : Selambat-lambatnya 7 (tujuh) hari kerja setelah penandatangan Akta Pemberian Hak Tanggungan sebagaimana dimaksud dalam Pasal 10 ayat (2), PPAT wajib mengirimkan Akta Pemberian Hak Tanggungan yang bersangkutan dan warkah lain yang diperlukan kepada Kantor Pertanahan dapat dikatakan bahwa perbuatan penyampaian Akta Pemberian Hak Tanggungan dan pendaftaran Akta Pemberian Hak Tanggungan dilakukan oleh PPAT. Dan apabila kreditur lalai dalam pendaftarannya/tidak mendaftarkannya, maka segala risiko dan akibat hukumnya terhadap jaminan yang diberikan oleh debitur tersebut tidak memberikan hak- hak istimewa yang diberikan oleh UUHT.

\section{Penutup}

\section{Kesimpulan}

Mekanisme pendaftaran Hak Tanggungan Elektronik secara elektronik merupakan layanan terobosan yang berbasis digital atau elektronik yang diluncurkan oleh Kementerian Agraria dan Tata Ruang/Badan Pertanahan Nasional untuk memudahkan pengurusan pertanahan berdasarkan asas keterbukaan, ketepatan waktu, kecepatan, kemudahan dan keterjangkauan dalam rangka pelayanan publik, serta untuk menyesuaikan perkembangan hukum, teknologi informasi agar prosedur pelayanan Hak Tanggungan sehingga menjadi lebih efektif dan efisien sehingga cita-cita untuk meningkatkan peringkat kemudahan berusaha atau ease of doing business (eodb).

\section{Saran}

Sebagai sistem baru yang masih memiliki kelemahan agar dapat terciptanya kepastian hukum mengenai pemberian jaminan Hak Tanggungan bagi para pihak yang berkepentingan, maka agar direvisi sesuai prinsip-prinsip dunia perkreditan dan prinsip prinsip hukum jaminan agar mekanisme pendaftaran Hak Tanggungan 
secara elektronik tidak menghambat aktivitas perkreditan sehingga para pihak yang berkepentingan dapat memaksimalkan pelayanan Hak Tanggungan secara elektronik. Agar pelayanan pendaftaran Hak Tanggungan secara manual tetap dimungkinkan sampaikan dengan adanya perbaikan dari segi sistem teknologi maupun aturan.

\section{DAFTAR PUSTAKA}

Buku

Alvin S. Johnson, Sosiologi Hukum, Cetakan ke 3, Asdi Mahastya, 2006.

Amiruddin dan H. Zainal Asikin, Pengantar Metode Penelitian Hukum, PT. Raja Grafindo Persada, Jakarta, 2006.

Arba, H.M, Hukum Agraria Indonesia, Sinar Grafika, Jakarta, 2015.

A Zainuddin, Metode penelitian hukum, Sinar Grafika, Jakarta, 2009.

Boedi Harsono, Hukum Agraria Indonesia, Himpunan Peraturan-Peraturan Hukum Tanah, Djambatan, Jakarta, 2008.

Boedi Harsono, Hukum Agraria IndonesiaSejarah Pembentukan UUPA, isi dan pelaksanaannya, Universitas Trisakti, Jakarta, 2013.

Djumhana, Muhammad, Hukum Perbankan di Indonesia, PT. Citra Aditya Bakti, Bandung, 2012.
Frieda Husni Hasbullah, Hukum Kebendaan Perdata Hak-Hak yang memberi Jaminan Jilid 2, Ind Hill-Co, Jakarta, 2009.

Hartono Hadisaputro, Pokok-pokok Hukum Perikatan dan Hukum Jaminan, Liberty, Yogyakarta, 1984.

Hardijan Rusli, Metode Penelitian Hukum Normatif, (Law Review, Volume V Nomor.3), Fakultas Hukum Universitas Pelita Harapan, Karawaci, 2006.

Hermanes R, Pendaftaran Tanah di Indonesia, Yayasan Karya Dharma Institut Ilmu Pemerintahan, Jakarta, 1994.

Hermansyah, Hukum Perbankan Nasional Indonesia, Kencana, Jakarta, 2008.

Lili Rasjidi, H. dan Ira Thania Rasjidi, Pengantar Filsafat Hukum, Mandar Maju, Bandung, 2011.

Mariam Darus Badrulzaman, Perjanjian Baku (Standard), Perkembangannya di Indonesia, Alumni, Bandung, 1980 .

Salim HS, Pengantar Hukum Perdata Tertulis (BW), Sinar Grafika, Jakarta, 2014.

Satrio, J, Hukum Jaminan Hak Jaminan Kebendaan, PT. Citra Aditya Bakti, Bandung, 2007.

Setiawan, R., Hukum Perikatan-Perikatan Pada Umumnya, Bina Cipta, Bandung, 1987. 
Soemarno Partodihardjo, Tanya Jawab Sekitar Undang-Undang No.11 Tahun 2008 Tentang Informasi Dan Transaksi Elektronik, PT Gramedia Pustaka Utama, Jakarta, 2009.

Subekti, R., Jaminan-Jaminan untuk Pemberian Kredit Menurut Hukum Indonesia, PT. Cipta Aditya Bakti, Jakarta, 1991.

Tan Thong Kie, Studi Notariat dan SerbaSerbi Praktek Notaris, PT. Ichtiar Baru Van Hoeve, Jakarta, 2007.

Peraturan Perundang-undangan

Kitab Undang-Undang Hukum Perdata / Burgerlijk Wetbook (BW).

Undang-Undang Nomor 5 Tahun 1960

Tentang Peraturan Dasar Pokok- Pokok Agraria.

Undang-Undang Nomor 4 Tahun 1996 Tentang Hak Tanggungan atas Tanah Beserta Bendabenda yang berkaitan dengan Tanah.

Undang-Undang Nomor 20 Tahun 2011

Tentang Rumah Susun.

Undang Undang Nomor 19 Tahun 2016 Tentang Perubahan atas UndangUndang Nomor 11 Tahun 2008
Tentang Informasi dan Transaksi Elektronik.

Peraturan Pemerintah Nomor 24 Tahun 1997

Tentang Pendaftaran Tanah.

Peraturan Menteri Agraria/Kepala Badan Pertanahan Nasional Nomor 3 Tahun 1997 tentang Ketentuan Pelaksanaan Peraturan Pemerintah Nomor 24 Tahun 1997 tentang Pendaftaran Tanah sebagimana diubah dengan Peraturan Kepala Badan Pertanahan Nasional Nomor 8 Tahun 2012 tentang Perubahan atas Peraturan Menteri Negara Agraria/ Kepala Badan Pertanahan Nasional Nomor 3 Tahun 1997 tentang Ketentuan Pelaksanaan Peraturan Pemerintah Nomor 24 Tahun 1997 Tentang Pendaftaran Tanah.

Peraturan Menteri Agraria Dan Tata Ruang/Kepala Badan Pertanahan Nasional Republik Indonesia Nomor 7 Tahun 2019 Tentang Perubahan Kedua Atas Peraturan Menteri Negara Agraria /Kepala Badan Pertanahan Nasional Nomor 3 Tahun 1997 Tentang Ketentuan Pelaksanaan Peraturan Pemerintah Nomor 24 Tahun 1997 Tentang Pendaftaran Tanah

Peraturan Menteri Agraria Dan Tata Ruang/Kepala Badan Pertanahan Nasional Republik Indonesia Nomor 3 Tahun 2019 Tentang Penerapan Tanda Tangan Elektroni 